\title{
Industrial Specialisation and Public Procurement: Theory and Empirical Evidence
}

\author{
Marius Brülhart* \\ Ecole des HEC University of Lausanne \\ Federico Trionfetti \\ Queen's University of Belfast Division of Economics
}

\begin{abstract}
Public-sector purchases from private firms account for over 10 percent of GDP in most developed countries, and they are typically biased in favour of domestic suppliers. This paper explores the impact of discriminatory public procurement on the location of industries. Our main theoretical finding is that, in a setting with increasing returns and trade costs, home-biased procurement can override other determinants of industrial specialisation. Our empirical analysis underscores the significance of discriminatory procurement. Drawing on a cross-country, crossindustry data sample for the EU, we find that determinants of industry location such as factor endowments, market access and intermediate inputs are significant in sectors where public procurement is small, but they lose their significance in sectors where public procurement is important.
\end{abstract}

- JEL Classifications: F12, F15, H57

- Key Words: Public Procurement, Industrial Specialisation, European Union

\section{Introduction}

This study investigates the effect of home-biased government procurement

\footnotetext{
*Corresponding Address: Marius Brülhart, Ecole des HEC University of Lausanne CH 1015 Lausanne Switzerland, Email: Marius.Brulhart@ hec.unil.ch

Federico Trionfetti, Queen's University of Belfast Division of Economics, 22 University Sq. Belfast B7 1NN United Kingdom, Email: F.Trionfetti@Queens-Belfast.ac.uk ( $2000-C e n t e r$ for International Economics, Sejong Institution, all Rights Reserved.
} 
on the pattern of international specialisation. By home bias we refer to the tendency of governments to allocate procurement expenditure in favour of domestic producers irrespective of their competitiveness relative to foreign suppliers. Home-biased procurement is akin to a non-tariff trade barrier and, as such, is likely to reduce aggregate welfare. Public procurement typically accounts for 10 to 12 percent of GDP in industrialised market economies. The sheer size of procurement and the negative welfare effects commonly associated with discrimination are the principal reasons why the liberalisation of public procurement has been afforded so much attention by the EU and the WTO.

This investigation eschews the issue of welfare effects and focuses on positive aspects. Specifically, we study the impact of discriminatory procurement on industry location. The hypothesis we subject to a test can be obtained from a fairly general model of international trade that incorporates constant returns sectors as well as increasing returns sectors, along the lines of Helpman and Krugman (1985, part III). In the basic model, factor endowments determine the inter-industry pattern of production and trade, while increasing returns and monopolistic competition explain intra-industry specialisation. To this general framework we add discriminatory procurement, which introduces product-market segmentation. The consequence is that discriminatory procurement can override factor endowments as determinants of industrial location. We put this theoretical result to a test by regressing an index of international specialisation on factor endowments, market size, and intermediate inputs. Our finding is that, when the regression includes all manufacturing sectors, the explanatory variables are significant and of the expected sign. When the regression includes only the sectors where government procurement is an important component of demand, none of the explanatory variables is statistically significant.

The paper is organised as follows. Section I motivates the paper with a summary account of relevant policy initiatives and earlier research. Some numerical evidence for the existence of home bias in public procurement is also given. The theoretical prediction is derived in Section II. In Section III, we produce relevant empirical evidence based on EU data. Section IV concludes.

\section{Why Public Procurement Matters}

\section{A. Policy Initiatives and Previous Research}

The opening-up of public procurement has been on the international policy 
agenda for many years, in the context both of European integration and of global trade liberalisation. Starting in 1977, the European Commission has issued numerous directives aimed at rendering the tendering procedures fully accessible to suppliers in all EU countries. This legislative effort has gathered momentum since the end of the 1980s, along with the completion of the Single Market. The latest measures have extended the coverage of non-discrimination rules to substantially all public and semi-public entities (CEC, 1996).

On the global scale, liberalisation of public procurement has been the objective of three multilateral treaties. The first one was signed in 1978, during the Tokyo Round of GATT negotiations. Most recently, the Government Procurement Agreement (GPA), was signed in parallel to the Uruguay Round in 1994 by 22 countries. The GPA, which entered into force in 1996, is considered to be on the frontier of juridical creativity because of its special enforcement mechanism. This mechanism, the Challenge Procedure, results in rapid settlements of disputes and can lead to the financial sanctioning of offenders (Hoekman and Mavroidis, 1997).

Although it is generally acknowledged that the legislative efforts of the EU and of the WTO have led to some liberalisation of public procurement, it is also commonly found that the implementation of the Commissions directives and of the GPA remains largely unsatisfactory (see above-cited studies).

Academic work on the economic implications of discriminatory public procurement has been rather scant. Perhaps the most important theoretical result is due to Baldwin $(1970,1984)$. Based on the standard Heckscher-Ohlin model, he argues that discriminatory government procurement is irrelevant for international specialisation. Miyagiwa (1991) shows that Baldwins proposition extends to a setup characterised by an oligopoly with homogeneous good. In this paper we reconsider the question in the context of a model featuring some sectors characterised by increasing returns and monopolistic competition, and we obtain quite different results.

A different line of research has studied the political interplay between the tendering entity and domestic and foreign bidders in various types of informational settings. This literature includes Branco (1994), McAfee and McMillan (1989), and a general treatment by Laffont and Tirole (1993). The bias in procurement stems from the fact that profits of domestic firms enter the objective function of government, while profits of foreign firms do not. These theoretical papers are based on partial-equilibrium analysis and neglect the effects of discriminatory procurement on resource allocation. We depart from this line of 
research in two ways. First, we cast our analysis in a general-equilibrium setting. Second, we search for the effect of home-biased procurement on the pattern of industrial specialisation.

Turning to welfare considerations, Chen (1995) finds a socially optimal discriminatory policy scheme which increases domestic output and reduces imports. Trionfetti (2000) focuses on the dynamic aspects of public procurement liberalisation in a "new economic geography" model. It is found that discriminatory procurement generates a dispersion force that may override agglomeration forces-a process which may be, but is not necessarily, welfare reducing. This study, however, eschews welfare considerations and focuses strictly on some positive consequences of discriminatory procurement.

On the empirical side, Hooker and Knetter (1997) study the defence sector in the United States. By linking defence procurement and employment data they show that shocks in US military spending have significant effects on State-level employment growth. Their study is not about international specialisation, but it is interesting because it relates "State-home-biased" procurement to the specialisation of the States within the US (although only for the defence sector). Their results broadly conform with the main message of this paper: variations in discriminatory public procurement result in substantial variations in productive activity.

\section{B. Stylised Facts on Government Procurement}

Our paper builds on the premise that government procurement is of significant magnitude as well as home biased. The magnitude of government procurement is well documented. In OECD countries, non-defence government purchases of goods and services from the private sector (excluding salaries) typically range between 10 and 12 percent of GDP (see UN(1995); IMF(1995); CEC(1997). This is clearly non-negligible. Given that procurement shares vary greatly across sectors, cross-sectional disaggregation is imperative for a properly specified analysis of this issue.

Even if it accounts for a large share of aggregate expenditure, public procurement is only of interest in the context of our study if it is also characterised by discriminatory practices. Based on survey results, the European Commission has already provided evidence of the discriminatory character of government procurement (CEC(1997)). We substantiate the proposition that biases are significant with some calculations based on the Eurostat input-output database (Eurostat, 1992). 
It is virtually impossible to ascertain directly whether a tendering entity is truly committed to awarding procurement contracts without bias. Indeed, even the formal respect of tendering rules does not guarantee that the tendering entity does not favour domestic bidders in other undetectable ways. Hence, it is more promising to focus on outcomes rather than on procedures. One way to measure the home bias via purchasing outcomes is to compare the import share of private sector $(M P)$ purchases with the import share of government purchases $(M G)$. We have computed the ratios of these shares $(M G / M P)$ for 12 manufacturing sectors and six EU countries. Absent any bias, the two shares should be similar, and the $M G / M P$ ratio should be close to one. Reasons other than home bias might of course explain differences between $M G$ and $M P$. Hence, we look for large differences between the two shares (ratios very different from one) as an indicator of bias. Table 1 reports the $M G / M P$ ratios for each country and sector.

Public-sector import shares are smaller than private-sector import shares in 80 percent of the reported sector-country combinations. More importantly, in most of these cases the difference is substantial. In 61 percent of the sector-country combinations the ratio is smaller than $2 / 3$, and 50 percent of them is smaller than $1 / 3$. In contrast, the inverse of this ratio $(M P / M G)$ is lower than $2 / 3$ only in 0.9

Table 1. Ratio of Import Shares by Public and Private Sectors in 6 EU Countries

(MG/MP, 1985)

\begin{tabular}{|c|c|c|c|c|c|c|}
\hline Industry & U.K. & Spain & Italy & Ireland & France & Germany \\
\hline Chemicals & 0.33 & 0.15 & 0.40 & 0.61 & 0.00 & 0.56 \\
\hline Metal products & 0.78 & 0.31 & 0.31 & 0.00 & 3.53 & 2.51 \\
\hline Industr. Machin. & 0.41 & 0.58 & 0.87 & 0.00 & 0.00 & 0.81 \\
\hline Office machines & 2.42 & 0.43 & 0.23 & 0.90 & 0.16 & 0.41 \\
\hline Electrical goods & 0.70 & 0.16 & 1.13 & 0.00 & 1.04 & 0.74 \\
\hline Motor vehicles & 0.83 & 0.00 & 0.27 & 0.16 & 1.39 & 0.70 \\
\hline Other transp. Eq. & 0.72 & 0.21 & 1.59 & 0.04 & 2.02 & 1.32 \\
\hline Textile, clothing & 0.03 & 0.00 & 1.06 & 0.60 & 0.00 & 0.78 \\
\hline Pulp, paper & 0.42 & 0.43 & 0.82 & 0.31 & 1.76 & 0.63 \\
\hline Printing & 0.26 & 0.43 & 2.35 & 0.24 & 0.66 & 0.99 \\
\hline Rubber, plastic & 0.27 & 0.00 & 0.04 & 0.19 & 0.00 & 1.42 \\
\hline Other manufact. & 0.92 & 0.00 & 0.00 & 1.05 & 0.22 & 1.23 \\
\hline Average* & 0.72 & 0.26 & 0.60 & 0.37 & 0.67 & 0.89 \\
\hline
\end{tabular}

Source: own computations based on Eurostat input-output database.

${ }^{*} \operatorname{Avg}(M G / M P)=\left(\sum_{s} M G_{s} / \sum_{s} M P_{s}\right)$, where $s$ denotes industries. 
percent of the combinations. Finally, averaging over sectors shows that in all countries the import share of government is considerably lower than the import share of the private sector. The ratio ranges from 0.26 (Spain) to 0.89 (Germany). The table provides prima facie evidence of a home-bias in EU public procurement in the 1980s - a pattern which has persisted into the 1990s according to the EU Commissions "Single Market Review” (CEC, 1997).

\section{Theory}

Our purpose is to examine whether discriminatory procurement may influence the pattern of specialisation. We choose a standard and versatile model of the "new trade theory", which features some increasing-returns sectors as well as constantreturns sectors. Specifically, we extend the model developed in Helpman and Krugman (1985, Part III) by introducing a government sector. This allows us to investigate the effects of discriminatory government procurement on international specialisation in a general-equilibrium setting.

The basic structure of the model is as follows. There are two homogeneous factors of production, generically labelled as $l$ and $k$; two countries, indexed by $i=1,2$; and three sectors, labelled $X, Y$, and $Z$ ( $Z$ will be dropped when we consider the squared model). Production technologies differ across sectors but are identical across countries. Sectors $Y$ and $Z$ are subject to a linearly homogeneous production function and operate under perfect competition. The average and marginal cost functions associated with these technologies are $c_{Y}\left(w_{i}, r_{i}\right)$ and $c_{Z}\left(w_{i}, r_{i}\right)$, where the arguments are the remuneration to $l$ and $k$ in $i$. The $X$ sector produces a differentiated commodity using a technology that requires a fixed cost $f\left(w_{i}, r_{i}\right)$ and a constant marginal cost $m\left(w_{i}, r_{i}\right)$. In order to make factor intensities independent of the scale of firms, we follow Markusen (1986) and assume that the functions $m\left(w_{i}, r_{i}\right)$ and $f\left(w_{i}, r_{i}\right)$ use factors in the same relative proportion. Thus, factor proportions in the manufacturing sector depend only on relative factor prices and not on the scale of firms. The average cost function of the manufacturing sector is $c_{X}\left(w_{i}, r_{i}\right)=m\left(w_{i}, r_{i}\right)+f\left(w_{i}, r_{i}\right) / x_{i}$, where $x$ denotes firms output. Demand functions for factors obtain from the cost functions through Shephards lemma. We denote these demand functions as $l_{s}\left(w_{i}, r_{i}\right)$ and $k_{s}\left(w_{i}, r_{i}\right)$ with $S=X, Y, Z$. Further, we assume no factor intensity reversals. Finally, it is assumed that commodities $Y$ and $Z$ are traded internationally at zero costs while commodity $X$ is traded internationally at a 
cost. It is assumed that trade costs are of the iceberg type. This means that for one unit shipped only a fraction $\tau \in(0,1)$ arrives at its destination. ${ }^{1}$

The total number of varieties produced in the world, denoted by $N$, is endogenously determined, and so is its distribution between countries. By definition, we have that $n_{1}=N-n_{2}$. The worlds factor endowment is exogenous and denoted by $L$ and $K$. Countries factors endowments are exogenous and, by definition, $l_{1}=L-l_{2}$ and $k_{1}=K-k_{2}$. The equilibrium equations are:

$$
\begin{array}{ll}
p_{S i}=c_{s}\left(w_{i}, r_{i}\right) & i=1,2 \text { and } S=X, Y, Z \\
p_{X i}(1-1 / \sigma)=m\left(w_{i}, r_{i}\right) & i=1,2 \\
l_{X}\left(w_{i}, r_{i}\right) x_{i} n_{i}+l_{Y}\left(w_{i}, r_{i}\right) y_{i}+l_{Z}\left(w_{i}, r_{i}\right) z_{i}=l_{i} & i=1,2 \\
k_{X}\left(w_{i}, r_{i}\right) x_{i} n_{i}+k_{Y}\left(w_{i}, r_{i}\right) y_{i}+k_{Z}\left(w_{i}, r_{i}\right) z_{i}=k_{i} & i=1,2
\end{array}
$$

Equations (1) state the usual conditions that average revenue equal average cost (zero profit condition) in all sectors and countries. For sectors $Y$ and $Z$, equations (1) also state the condition that marginal revenue equal marginal costs (profit maximisation). Equation (2) states the profit maximising condition for the $X$ sector. Equations (3) and (4), where $y$ and $z$ denote output levels, represent the factor-market clearing conditions.

To close the model, we need to describe the demand side in its two components, private and public. Households in both countries are assumed to have homothetic preferences. Specifically, we assume Dixit-Stiglitz preferences (i.e., a nested Cobb-Douglas-CES utility function) with Cobb-Douglas expenditure shares $v_{s i}(S=X, Y, Z)$ and $\Sigma_{s} v_{s i}=1$, and with elasticity of substitution of the CES sub-utility equal to the constant $\sigma \in(1, \infty)$. Households are taxed in a lump-sum fashion. Homothetic preferences assure that the distribution of taxation among households does not affect aggregate demand. Maximisation of utility subject to the budget constraint yields households demand functions. Aggregating across households gives demand functions for the differentiated good. Country is private demand for each variety produced in $i$ is $x_{i}=p_{X i}^{-\sigma} P_{i}^{1-\sigma} v_{X i} I_{i}^{d} . P_{i}$ is the price index applicable to country $i, I_{i}^{d}=\left(1-\delta_{i}\right) I_{i}$ is households disposable income, $\delta_{i}$ is a taxation parameter and $I_{i}$ is the inner product between the vector of factor endowments and the vector of factor

\footnotetext{
The introduction of three goods and two factors is made necessary by the fact that trade costs cause the loss of one degree of freedom in the model. In order to restore a factor price equalisation set of full dimensionality there is need for an additional equation (an additional good).
} 
prices (households have claims on $k$ ). Because of trade costs, country $i$ s private demand for each variety produced in $j$ is $x_{i}=\tau^{\sigma} p_{X i}^{-\sigma} P_{i}^{1-\sigma} v_{X i} I_{i}^{d}$. Since profits are zero $I_{i}$ is national income. For future reference, we define private expenditure on the $X \operatorname{good}$ as $E_{X i}^{P} \equiv v_{X i}\left(1-\delta_{i}\right) I_{i}$.

The model described so far is standard (see Helpman and Krugman, 1985). We now introduce government procurement. Governments purchase goods that they use for their subsistence. The balanced budget requirement assures that expenditure equals tax collection. Tax collection amounts to $\delta_{i} I_{i}$ and is allocated among goods according to the parameter $\gamma_{S i}(S=X, Y, Z)$ with $\Sigma_{S} \gamma_{S i}=1$. Government is expenditure on the aggregate of manufactures is then $E_{X i}^{G} \equiv \gamma_{X i} \delta_{i} I_{i}{ }^{2}$

We introduce a parameter that represents governments bias in favour of domestically produced goods: $\phi_{i} \in[0,1]$. Specifically, a proportion $\phi_{i}$ of government $i$ s purchases is reserved to domestic producers. The remainder of government expenditure is allocated efficiently among all the $N$ varieties produced in the world. This simple assumption approximates two common discriminatory practices: (1) the outright exclusion of foreign bidders from some domestic public tenders and (2) domestic-content requirements imposed on foreign firms. It is the same assumption adopted in Baldwin $(1970,1984)$. A large $\phi_{i}$ means a strong home bias. For clarity of exposition we shall say that government is procurement is "fully liberalised" if $\phi_{i}=0$, "discriminatory" if $\phi_{i} \in[0,1]$, and "fully discriminatory" if $\phi_{i}=1$.

\section{A. Equilibrium in the Product Market}

Equilibrium in the product market requires the following equations to hold:

$$
\begin{gathered}
p_{Z} Z=v_{Z 1}\left(1-\delta_{1}\right) I_{1}+\gamma_{Z 1} \delta_{1} I_{1}+v_{Z 2}\left(1-\delta_{2}\right) I_{2}+\gamma_{Z 2} \delta_{2} I_{2} \\
p_{X}\left(n_{1} x_{1}+n_{2} x_{2}\right)=v_{X 1}\left(1-\delta_{1}\right) I_{1}+\gamma_{X 1} \delta_{1} I_{1}+v_{X 2}\left(1-\delta_{2}\right) I_{2}+\gamma_{X 2} \delta_{2} I_{2} \\
p_{X 1} x_{1}= \\
\left(p_{X 1}^{1-\sigma} P_{1}^{\sigma-1}\left[E_{X 1}^{P}+\left(1-\phi_{1}\right) E_{X 1}^{G}\right]+\theta p_{X 1}^{1-\sigma} P_{2}^{\sigma-1}\left[E_{X 2}^{P}+\left(1-\phi_{2}\right) E_{X 2}^{G}\right]+\left(\phi_{1} / n_{1}\right) E_{X 1}^{G}\right)
\end{gathered}
$$

\footnotetext{
${ }^{2}$ The micro foundation of government behaviour is not our main concern. It is worth pointing out, however, that the behaviour described in the text can be formalised by assuming that governments produce a public good according to a Cobb-Douglas-CES production function with parameter shares gs, and with elasticity of substitution of the CES aggregate equal to the constant. The constant per capita tax results from Lindahl-type taxation if we assume that the public good enters the utility function in a separable way. See Trionfetti (2000) for details.
} 
where $\theta \equiv \tau^{\sigma-1}$. Equations (5)-(7) close the model. Equation (5) equates supply and demand for $Z$, where demand (r.h.s.) is represented in its four components: country $1 \mathrm{~s}$ private and public and country $2 \mathrm{~s}$ private and public expenditure. Equilibrium in the $X$ sector is described in two equations. Equation (6) is analogous to (5); world supply of $X$ (1.h.s) must equal world demand for $X$ (r.h.s.), where the latter is represented in its four components. Further, since trade costs create market segmentation, we also need to equate demand and supply for each variety produced in 1 or 2 . Since this equilibrium condition is identical (linearly dependent) for all varieties, it suffices to state only one of them. Equation (7) expresses this condition. The supply of each variety of $X$ produced in 1 (1.h.s) must equal demand for each variety of $X$ produced in 1 (r.h.s.). If (6) and (7) hold, then the market for the varieties produced in 2 is also in equilibrium. By Walras law the equilibrium condition for $Y$ is redundant.

We are interested in finding how the pattern of specialisation relates to private expenditure, and discriminatory government expenditure. The presence of trade costs prevents us from deriving a simple reduced form from the model. However, we can find the relationship we are interested in by totally differentiating of system (1)-(7) with respect to the changes in private and public expenditure. For simplicity let us assume that the changes in expenditure derive from changes in the Cobb-Douglas shares, i.e., $d E_{X i}^{G}=\delta_{i} I_{i} d \gamma_{X i}$ and $d E_{X i}^{G}=\left(1-\delta_{i}\right) I_{i} d v_{X i}$.

Defining

$$
\begin{gathered}
\eta \equiv n_{1} / N \\
\varepsilon^{P} \equiv E_{X 1}^{P} /\left(E_{X 1}^{P}+E_{X 2}^{P}\right), \varepsilon^{G} \equiv E_{X 1}^{G} /\left(E_{X 1}^{G}+E_{X 2}^{G}\right), \\
E_{W} \equiv E_{X i}^{P}+E_{X 2}^{P}+E_{X i}^{G}+E_{X i}^{G}, E_{W}^{G} \equiv E_{X i}^{G}+E_{X i}^{G},
\end{gathered}
$$

and differentiating the system gives the following expression: ${ }^{3}$

$$
d \eta=\frac{\left(1-\theta^{2}\right)}{(1-\theta)^{2} E_{W}+4 \phi \theta E_{W}^{G}} d \varepsilon^{P}+\frac{\left[\left(1-\theta^{2}\right)+4 q f\right]}{(1-\theta)^{2} E_{W}+4 \phi \theta E_{W}^{G}} d \varepsilon^{G}
$$

The first term on the r.h.s. is the size effect of private expenditure. In essence, it implies that large private expenditure on $X$ results in large domestic output of $X$. The second term is the size effect of government expenditure. It implies that large discriminatory government expenditure on $X$ results in large domestic output of $X$.

\footnotetext{
${ }^{3}$ In order to simplify algebra, differentiation is taken at the equilibrium point where $\delta_{1}=\delta_{2}$ and $\phi_{1}=\phi_{2}$. The equilibrium is disturbed by $d \gamma_{S 1}=-d \gamma_{S 2}, d v_{S 1}=-d v_{S 2}$, and $d \phi_{1}=-d \phi_{2}$.
} 
Note first that if government procurement is fully liberalised $(\phi=0)$ the model reverts to the Helpman-Krugman (1985, section 10.4) model where the specialisation pattern in the $X$ sector is determined by the size of (private plus liberalised public) expenditure. Since there are assumed to be more goods than factors, factor-price equalisation obtains in spite of trade costs. Thus, quite trivially, factor endowments do not play any direct role in determining the pattern of specialisation. They influence the pattern of specialisation indirectly, however, insofar as they effect income and, through income, the size of expenditure in each country. In the empirical investigation, we therefore include factor endowments among the explanatory variables.

We want to focus, however, on discriminatory procurement. The first coefficient on the r.h.s. of (8) decreases as government procurement becomes larger and/or more home biased. This has an important implication. It means that a country with small local (private) demand for $X$ need not to have small domestic output of $X$, because the effect of private demand on output is small when government demand is large and home biased. In addition, the effect of private demand may be overridden by large and home-biased government demand. We also observe that the second coefficient is larger than the first one as long as government procurement is not fully liberalised. This means that a 1 percent variation in $\varepsilon^{G}$ overrides a 1 percent variation in $\varepsilon^{P}$ of opposite sign. That is, if $d \varepsilon^{G}=-d \varepsilon^{P}$, then $d \eta$ takes the sign of $d \varepsilon^{G}$. This is our key result: both the size and the degree of bias of public procurement matter for international specialisation in increasing-returns sectors, and discriminatory procurement can offset other locational determinants.

If appropriate data were available, one could subject expression (8) to an empirical test. Unfortunately, while quantitative information on $\delta_{i}$ exists, available data on $\gamma_{x i}$ and $\phi_{i}$ are only qualitative. For instance, with respect to $\gamma_{x i}$, we know in which sectors government procurement is an important component of demand and in which sectors it is not, and we call the former "procurement sensitive" sectors and the latter "procurement insensitive". We do not have quantitative measures of $\gamma_{x i}$ that can be used for empirical purposes. Yet, expression (8) tells us that discriminatory government procurement interferes with other location determinants. We put this result to an empirical test.

\section{Empirical Evidence for The European Union}

An empirical test of the predictions generated by our model requires two 
ingredients: suitable data and an econometric model. We discuss these issues first and then report results.

\section{A. Data}

The demands on data of a fully specified test for our model are formidable. We would need a three-dimensional panel, with geographical, industry and time dimensions. Ideally, each observation would provide information on each of the three dimensions for the size of the industry, the level of trade costs, factor requirements and rewards, the importance of government purchasing and the home-bias of government purchases. Such a data set does not exist. We therefore have to concentrate on what is essential as well as feasible.

The EU provides the best case study for our purpose, since, uniquely to our knowledge, comparable cross-country data on both the levels and the home-biases in public procurement are available (CEC, 1997). In the trade-off between crossindustry and cross-location disaggregation, we have opted for country rather than regional data, hence allowing a higher level of industry disaggregation. When it comes to the choice of measurement units, most studies of international specialisation use exports as a proxy for industry size. Yet, the size of industries in terms of employment or output correlates less than perfectly with the value of their exports. Hence, we use production rather than trade statistics, at the cost of a higher level of sectoral aggregation.

Due to incomplete statistical reporting by EU countries, a second trade-off exists between the number of sample years and the number of cross-sectional observations. A panel data set would be highly unbalanced. We therefore conduct a cross-sectional study using data for 1989, when coverage was most comprehensive. Our data set, drawing on the Eurostat series "Structure and Activity of Industry", covers 82 NACE 3-digit manufacturing industries in nine EU countries. ${ }^{4}$

The value and home bias of public procurement are notoriously difficult to measure. Through the public procurement study of the EU Commissions "Single Market Review" (CEC, 1997), however, we avail of some relevant information for non-defence procurement in the EU. Unfortunately, there are no data on the importance of public procurement by industry and country. Across industries, the

\footnotetext{
${ }^{4}$ The Netherlands, Ireland and Luxembourg had to be excluded because of incomplete data coverage. The industries in the sample accounted for 22.5 million manufacturing jobs, which represented 96.7 percent of 1989 industrial employment in the nine countries. For a summary data description, see Appendix Table 1.
} 
report identifies twelve sectors which are significantly affected by public procurement, without, however, quantifying the importance of procurement in each of these industries. ${ }^{5}$ The authors of the report estimate that the twelve sensitive sectors account for 62 percent of the value of public procurement.

\section{B. Econometric Specification}

Our independent variable is derived from the specialisation index proposed by Hoover (1936): ${ }^{6}$

$$
L_{i j}^{H}=\frac{S_{i j}}{\sum_{i} S_{i j}} / \frac{\sum_{j} S_{i j}}{\sum_{i} \sum_{j} S_{i j}},
$$

where $S_{i j}$ is the size of industry $i$ in country $j$, expressed in terms of either employment or production. $L^{H}$ is non-negative, and a value greater/smaller than one means the share of industry $i$ is larger/smaller in country $j$ than the average over all countries. We apply two transformations to this index, resulting in the following specialisation measure:

$$
L_{i j}=\ln \left(\frac{S_{i j}}{\sum_{i} S_{i j}} \underset{j=[1, n]}{m e d i a n}\left[\frac{S_{i j}}{\sum_{i} S_{i j}}\right]\right)
$$

In the first transformation, we have re-defined the denominator as the median, rather than the mean, of the share of industry $i$ across the $n$ sample countries. This eliminates the purely statistical effect of country size on the value taken by the specialisation index: without our adjustment, the variability of the index relates negatively to country size. The second transformation is to take the natural logarithm of the underlying ratio. The effect of this modification is to centre the measure symmetrically around zero. ${ }^{7}$

Having defined our dependent variable, we proceed to estimate the following

\footnotetext{
${ }^{5}$ These sectors are (NACE codes in brackets): boilers and vessels (315), metal office furniture (316), office machinery (330), cables and wires (341), power generating equipment (342), telecoms equipment (344), motor vehicles (351), railway rolling stock (362), medical equipment (370), textiles and clothing (453), and paper $(471,472)$.

${ }^{6}$ This index is sometimes attributed to Balassa (1965).

${ }^{7}$ A summary statistical description of all dependent and independent variables is given in Appendix Table 1. The full set of values on the specialisation measure, calculated from employment data, is provided in Appendix Table 2.
} 
basic equation:

$$
L_{i j}=\alpha_{i j}+\boldsymbol{\beta}^{k} \boldsymbol{X}_{i j}^{k}+\varepsilon_{i j}
$$

where $\boldsymbol{X}$ is a vector containing sets of location determinants, labelled by $k$. We concentrate on three sets of locational determinants.

First, we specify "Heckscher-Ohlin" determinants:

$$
\boldsymbol{\beta}^{k} \boldsymbol{X}_{i j}^{l}=\beta_{1}^{1} \operatorname{LINTENS}_{i}+\beta_{2}^{1} \operatorname{LABUND}_{j}+\beta_{3}^{1} \operatorname{LINTENS}_{i}{ }^{*} \operatorname{LABUND}_{j}
$$

where LINTENS, the measure for labour intensity, is defined as an industrys ratio of labour costs to the value of production, computed across all countries. Correspondingly, $L A B U N D$, the measure for labour abundance, is a countrys ratio of labour costs to the value of production, computed across industries. We define all non-labour inputs as one production factor. Consequently, we can model the standard factor proportion prediction, whereby labour (capital) abundant countries will specialise in labour (capital) intensive industries, by interacting the two variables in (14).

Second, we specify determinants derived from "new trade theory" models:

$$
\boldsymbol{\beta}^{2} \boldsymbol{X}_{i j}^{2}=\beta_{1}^{2} S C A L E_{i}+\beta_{2}^{2} C E N T R A L_{j}+\beta_{3}^{2} S C A L E_{i}^{*} C E N T R A L_{j}
$$

where SCALE, the measure for scale economies, is defined as an industry's average output per firm. CENTRAL, our proxy for market size, is calculated as each country's centrality index, obtained from Keeble et al. (1986). The variables are interacted in order to reflect the stylised prediction of the theory that scale-sensitive industries will locate in countries with access to large markets (Krugman, 1980).

Third, we specify determinants derived from "new economic geography" models:

$$
\begin{gathered}
\boldsymbol{\beta}^{3} \boldsymbol{X}_{i j}^{3}= \\
\beta_{1}^{3} \operatorname{INTERMIND}_{i}+\beta_{2}^{2} \operatorname{INTERMIND}_{j}+\beta_{3}^{2} \operatorname{INTERMIND}_{i}{ }^{*} \operatorname{INTERMCTR}_{j}(14)
\end{gathered}
$$

where INTERMIND measures the intermediate-input intensity of industries. Following Amiti (1997), intermediate-good intensity is measured as the difference between production and value added. INTERMCTR represents the availability in a country of intermediate inputs, also calculated as the difference between production and value added. This can be interpreted as a proxy for a countrys 
"industrial base" (Venables, 1996). The variables are interacted, since we expect intermediate-input intensive industries to be relatively larger in intermediate-input abundant countries. ${ }^{8}$

The theoretical part of this paper argues that in the sectors where government procurement is large and home biased (the "procurement sensitive" sectors) government procurement interferes with other specialisation determinants. We test this prediction by running two separate regression of (11), one for the sensitive sectors and one for the non-sensitive sectors.

\section{Results}

In Appendix Table 2, we report the values of our specialisation measure, the dependent variable of subsequent analysis. Industries are ranked in decreasing order by the standard deviation of specialisation measures across countries. Hence, the further down an industry is placed in Appendix Table 2, the more dispersed it is across our nine sample countries. ${ }^{9}$ One might glean some prima facie evidence on the localisation pattern of procurement-sensitive industries from this table, with the expectation that they should be positioned towards the bottom of the list. However, we find that the industries singled out in CEC (1997) are distributed quite evenly across our ranking, with two sectors standing out near the top of the list: data processing and railway rolling stock. Simple visual inspection of the data, therefore, gives us no reason to suspect an impact of public procurement on industrial specialisation in the EU. However, a valid test of the hypothesis that public procurement can offset other location determinants needs to introduce controls for the latter.

In a second step, we have split our sample into observations pertaining to industries which are (or are not) significantly affected by public procurement. The results for the "procurement insensitive" industries are given in the third and fourth data columns of Table 2. Our model survives in this sub-sample: the signs and significance levels on interaction terms are unchanged. Hence, the location determinants suggested by economic theory seem to have significant location effects in those industries where public procurement plays an insignificant role.

\footnotetext{
${ }^{8}$ All interacted explanatory variables are constructed as deviations from their means. This "centring" of interacting variables minimises multicollinearity problems (see Jaccard et al., 1990).

${ }^{9}$ Similarly, countries are ranked in decreasing order of the standard deviation across industries, from left to right.
} 
Table 2. Determinants of Industrial Specialisation in the EU, 1989

\begin{tabular}{|c|c|c|c|c|c|c|}
\hline $\begin{array}{c}\text { Industries } \\
\text { (no. of } \\
\text { observations) }\end{array}$ & $\begin{array}{l}\text { All } \\
(684)\end{array}$ & $\begin{array}{c}\text { All } \\
(684)\end{array}$ & $\begin{array}{c}\text { Procure- } \\
\text { ment } \\
\text { insensitive } \\
(588)\end{array}$ & \begin{tabular}{|c|} 
Procure- \\
ment \\
insensitive \\
$(588)$
\end{tabular} & $\begin{array}{l}\text { Procure- } \\
\text { ment } \\
\text { sensitive } \\
(96)\end{array}$ & $\begin{array}{l}\text { Procure- } \\
\text { ment } \\
\text { sensitive } \\
(96)\end{array}$ \\
\hline Dependent var. & Employment & Production & Employment & Production & Employment & Production \\
\hline $\mathrm{CON}$ & $\begin{array}{l}-0.02 \\
(-0.75)\end{array}$ & $\begin{array}{l}-0.02 \\
(-0.69)\end{array}$ & $\begin{array}{l}-0.01 \\
(-0.29)\end{array}$ & $\begin{array}{l}-0.01 \\
(-0.51)\end{array}$ & $\begin{array}{l}-0.06 \\
(-1.07)\end{array}$ & $\begin{array}{c}0.01 \\
(0.18)\end{array}$ \\
\hline LIN & $\begin{array}{c}0.30 \\
(0.35)\end{array}$ & $\begin{array}{l}-0.03 \\
(-0.03)\end{array}$ & $\begin{array}{c}0.11 \\
(0.11)\end{array}$ & $\begin{array}{l}-0.28 \\
(-0.32)\end{array}$ & $\begin{array}{c}2.50 \\
(0.82)\end{array}$ & $\begin{array}{c}2.74 \\
(0.86)\end{array}$ \\
\hline $\mathrm{LAB}$ & $\begin{array}{l}-0.91 \\
(-0.85)\end{array}$ & $\begin{array}{l}-0.39 \\
(-0.36)\end{array}$ & $\begin{array}{l}-1.09 \\
(-0.93)\end{array}$ & $\begin{array}{l}-0.36 \\
(-0.31)\end{array}$ & $\begin{array}{l}-0.67 \\
(-0.25)\end{array}$ & $\begin{array}{l}-2.00 \\
(0.68)\end{array}$ \\
\hline $\begin{array}{l}\text { LINTENS* } \\
\text { LABUND }\end{array}$ & $\begin{array}{l}31.63 \\
(2.64)^{* * *}\end{array}$ & $\begin{array}{l}43.01 \\
(3.73)^{* * * *}\end{array}$ & $\begin{array}{l}26.31 \\
(2.06)^{* *}\end{array}$ & $\begin{array}{l}37.79 \\
(3.20)^{* * *}\end{array}$ & $\begin{array}{c}47.91 \\
(1.32)\end{array}$ & $\begin{array}{r}73.07 \\
(1.54)\end{array}$ \\
\hline$S C A L E\left(* 10^{-6}\right)$ & $\begin{array}{l}-121.93 \\
(-0.91)\end{array}$ & $\begin{array}{l}-16.13 \\
(-0.12)\end{array}$ & $\begin{array}{c}-64.78 \\
(-0.49)\end{array}$ & $\begin{array}{c}28.71 \\
(0.21)\end{array}$ & $\begin{array}{l}-890.03 \\
(-1.42)\end{array}$ & $\begin{array}{l}-751.77 \\
(-1.16)\end{array}$ \\
\hline $\begin{array}{c}\text { CENTRAL } \\
\left(* 10^{-6}\right)\end{array}$ & $\begin{array}{l}-7.64 \\
(-0.62)\end{array}$ & $\begin{array}{l}-16.31 \\
(-1.26)\end{array}$ & $\begin{array}{l}-13.51 \\
(-1.01)\end{array}$ & $\begin{array}{l}-21.26 \\
(-1.54)\end{array}$ & $\begin{array}{l}26.25 \\
(0.89)\end{array}$ & $\begin{array}{r}12.17 \\
(0.37)\end{array}$ \\
\hline $\begin{array}{c}\text { SCALE* } \\
\text { CENTRAL } \\
\left(* 10^{-6}\right)\end{array}$ & $\begin{array}{c}0.17 \\
(3.28)^{* * *}\end{array}$ & $\begin{array}{l}0.14 \\
(2.79)^{* * *}\end{array}$ & $\begin{array}{c}0.15 \\
(3.02)^{* * *}\end{array}$ & $\begin{array}{c}0.12 \\
(2.52)^{* *}\end{array}$ & $\begin{array}{c}0.41 \\
(1.74)^{*}\end{array}$ & $\begin{array}{c}0.40 \\
(1.63)\end{array}$ \\
\hline INTERMIND & $\begin{array}{c}0.52 \\
(0.71)\end{array}$ & $\begin{array}{c}0.22 \\
(0.32)\end{array}$ & $\begin{array}{c}0.29 \\
(0.38)\end{array}$ & $\begin{array}{l}-0.10 \\
(-0.14)\end{array}$ & $\begin{array}{c}3.38 \\
(1.17)\end{array}$ & $\begin{array}{c}4.47 \\
(1.44)\end{array}$ \\
\hline INTERMCTR & $\begin{array}{l}-0.65 \\
(-0.89)\end{array}$ & $\begin{array}{l}-1.28 \\
(-1.67)^{*}\end{array}$ & $\begin{array}{l}-0.84 \\
(-1.04)\end{array}$ & $\begin{array}{l}-1.50 \\
(-1.73)^{*}\end{array}$ & $\begin{array}{c}0.54 \\
(0.27)\end{array}$ & $\begin{array}{c}0.03 \\
(0.01)\end{array}$ \\
\hline $\begin{array}{l}\text { INTERMIND* } \\
\text { INTERMCTR }\end{array}$ & $\begin{array}{c}18.82 \\
(2.22)^{* * *}\end{array}$ & $\begin{array}{c}12.94 \\
(1.69)^{*}\end{array}$ & $\begin{array}{c}19.69 \\
(2.18)^{* *}\end{array}$ & $\begin{array}{c}14.08 \\
(1.71)^{*}\end{array}$ & $\begin{array}{r}21.64 \\
(0.85)\end{array}$ & $\begin{array}{r}17.13 \\
(0.69)\end{array}$ \\
\hline $\begin{array}{c}\text { Ramsey } \\
\text { RESET } \\
\text { test }(\operatorname{Pr}>\mathrm{F})\end{array}$ & $\begin{array}{c}1.40 \\
(0.24)\end{array}$ & $\begin{array}{c}0.95 \\
(0.41)\end{array}$ & $\begin{array}{c}0.90 \\
(0.44)\end{array}$ & $\begin{array}{c}0.62 \\
(0.60)\end{array}$ & $\begin{array}{c}3.04 \\
(0.03)\end{array}$ & $\begin{array}{c}1.39 \\
(0.25)\end{array}$ \\
\hline $\begin{array}{c}\mathrm{F} \text { test on all } \\
\text { variables } \\
(\mathrm{Pr}>\mathrm{F})\end{array}$ & $\begin{array}{c}4.32 \\
(0.00)\end{array}$ & $\begin{array}{c}5.29 \\
(0.00)\end{array}$ & $\begin{array}{c}3.83 \\
(0.00)\end{array}$ & $\begin{array}{c}4.47 \\
(0.00)\end{array}$ & $\begin{array}{c}1.54 \\
(0.15)\end{array}$ & $\begin{array}{c}2.89 \\
(0.01)\end{array}$ \\
\hline $\mathrm{R}^{2}$ & 0.07 & 0.06 & 0.06 & 0.06 & 0.19 & 0.20 \\
\hline
\end{tabular}

Notes: dependent variable $=$ specialisation measure based on production or employment; White-corrected t values in brackets, ***, **, *: significant at $1 \%, 5 \%$ and $10 \%$ levels.

This picture changes when we look at the results for the sub-sample of "procurement sensitive" industries, listed in the last two columns of Table 2. The statistical significance levels on all interaction terms drop sharply, and none retains significance at the 5 percent level. ${ }^{10}$ In the employment specification, the 
RESET test strongly suggests specification error or omitted variables. Public procurement thus appears to reduce the relevance of the location determinants identified in the three groups of independent variables. We find that factor endowments, centrality, and intermediate inputs are of little statistical significance as determinants of industrial location in the sectors with important public procurement. Hence, public procurement appears to influence the spatial distribution of industry significantly.

Some caution must be applied in the interpretation of this result, since the twelve industries tagged as procurement-sensitive might happen to share other distinctive but unknown characteristics which significantly influence the location decisions of firms. Yet, it is difficult to dismiss the corroborative force of the fact that the sectors tagged as sensitive by the CEC (1997) are exactly those who happen to perform very differently in comparison to the other sectors in our econometric exercise.

\section{Conclusions}

Public procurement accounts for fully 10 percent of GDP in developed countries, and is typically characterised by significant bias in favour of domestic suppliers. Motivated by the empirical importance of this phenomenon, we have explored the proposition that home-biased public purchasing significantly affects the spatial distribution of industries.

We have extended a model from the new trade literature and shown that discriminatory government procurement can countervail the pattern of specialisation which would emerge as a result of the influence of factor endowments. A crosssection analysis of industrial specialisation across nine EU countries supports the theoretical priors. Whilst determinants of industry location such as factor endowments, market access and availability of intermediate inputs are significant in sectors where public procurement is small, these locational determinants lose significance in those industries for which public procurement is an important part of demand.

Our work points to the importance of further empirical exploration. There is

\footnotetext{
${ }^{10}$ It might be suspected that the loss of statistical significance in the regression runs on the sample of procurement-sensitive industries is due to the smaller number of observations in that sample. We have explored this proposition by drawing random samples of 96 observations among the "insensitive" industries, and we re-ran the regression on those sub-samples. Statistical significance was found in all sub-samples of the "insensitive" set. Hence, differences in sample size do not seem to be driving our results.
} 
obviously scope for estimating the equations suggested here on data for other periods and countries. A data set with full numerical information on the size and bias of government procurement by industry and country would allow a complete and rigorous test of our model. Moreover, theoretical work on welfare effects of biased procurement should be encouraged. Our results show that public procurement practices impact noticeably on the location of industries. It remains to be explored how costly these distortions are in terms of efficiency losses.

\section{Acknowledgements}

The authors benefited from participation in a research network financed by a grant of the European Science Foundation and obtained financial support from the Provosts Academic Development Fund, Trinity College Dublin and from the British Economic and Social Research Council ("Evolving Macroeconomy" programme, ESRC grant L138251002). We are grateful to Jonathan Eaton, Carolyn Evans, Philip Lane and Dermot McAleese for helpful comments.

Date accepted: 23 October 2000

\section{References}

Amiti, Mary (1997) "Specialisation Patterns in Europe”. CEP Discussion Paper, No. 363, London School of Economics.

Balassa, Bela (1965) "Trade Liberalisation and Revealed Comparative Advantage". Manchester School, 33, 99-123.

Baldwin, Robert E. (1970) Nontariff Distortions of International Trade. Brookings Institution, Washington, DC.

Baldwin, Robert. E. (1984) "Trade Policies in Developed Countries". In: R. Jones and P.

Kenen (eds.) Handbook of International Economics. Amsterdam, North Holland.

Branco, Fernando (1994) "Favoring Domestic Firms in Procurement Contracts". Journal of International Economics, 37, 65-80.

Brülhart, Marius (1998) "Trading Places: Industrial Specialisation in the European Union”. Journal of Common Market Studies, 36(3).

Chen, Xiangqun (1995) "Directing Government Procurement as an Incentive to

Production". Journal of Economic Integration 10, 130-140.

Commission of the European Communities (CEC) (1996) "Public Procurement in the 
European Union: Exploring the Way Forward". Green Paper, CEC/DG XV, Brussels.

Commission of the European Communities (CEC) (1997) Single Market Review: Public Procurement. Kogan Page, London.

Dixit, Avinash and Stiglitz, Joseph E. (1977) "Monopolistic Competition and Optimum Product Diversity". American Economic Review, 67, 297-308.

Helpman, Elhanan and Krugman, Paul (1985) Market Structure and Foreign Trade. MIT Press, Cambridge MA.

Hoekman, Bernard M. and Petros C. Mavroidis (1997) Law and Policy in Public Purchasing, University of Michigan Press, Ann Arbor.

Hooker, Mark A. and Knetter, Michael M. (1997) "The Effects of Military Spending on Economic Activity: Evidence from State Procurement Spending”. Journal of Money, Credit and Banking, 29, 400-423.

Hoover, Edgar M. (1936) "The Measurement of Industrial Localisation". Review of Economics and Statistics, 18, 162-171.

International Monetary Fund (IMF) (1995) Government Finance Statistics, IMF, Washington, D.C.

Jaccard, James; Turrisi, Robert and Choi K. Wan (1990) Interaction Effects in Multiple Regression. Newbury Park CA., Sage Publications.

Keeble, David; Offord, John and Walker, Sheila (1986) Peripheral Regions in a Community of Twelve Member States. Commission of the European Communities, Luxembourg.

Krugman, Paul (1980) "Scale Economies, Product Differentiation, and the Pattern of Trade". American Economic Review, 70, 950-959.

Laffont, Jean-Jacques and Tirole, J. (1993) A Theory of Incentives in Procurement and Regulation. MIT Press, Cambridge, MA.

Markusen, James R. (1986) "Explaining the Volume of Trade: An Eclectic Approach". American Economic Review, 76, 1002-1011.

McAfee, R. Preston and McMillan, John (1989) "Government Procurement and International Trade”. Journal of International Economics, 26, 291-308.

Miyagiwa, Kaz (1991) "Oligopoly and Discriminatory Government Procurement Policy". American Economic Review, 81, 1321-1328.

Smith, Alasdair (1994) "Imperfect Competition and International Trade". In: Greenaway, D. and Winters L.A. (eds.) Surveys in International Trade, Blackwell, Oxford.

Trionfetti Federico (2000) "Government Procurement, Economic Integration, and Income Inequality". Review of International Economics, forthcoming.

United Nations (UN) (1995) National Accounts Statistics, Part I. UN Publishing Division, New York.

Venables, Anthony (1996) "Equilibrium Location of Vertically Linked Industries", International Economic Review, 37, 341-359. 


\section{Appendix}

Table 1. Data Description

\begin{tabular}{|c|c|c|c|c|c|c|}
\hline Variable* & \multicolumn{1}{|c|}{ Mean } & Std. Dev. & Min. & \multicolumn{1}{c|}{ Max. } & Min. Observ. & Max. Observ. \\
\hline $\begin{array}{c}\text { Specialisation } \\
\text { measure (empl.) }\end{array}$ & -0.01 & 0.67 & -2.39 & 2.34 & $\begin{array}{c}\text { Greece: } \\
\text { Transform. of metals }\end{array}$ & $\begin{array}{c}\text { Portugal: } \\
\text { Cotton }\end{array}$ \\
\hline $\begin{array}{c}\text { Specialisation } \\
\text { measure (prod.) }\end{array}$ & -0.01 & 0.68 & -2.53 & 2.13 & $\begin{array}{c}\text { Greece: } \\
\text { Transform. of metals }\end{array}$ & $\begin{array}{c}\text { Portugal: } \\
\text { Cotton }\end{array}$ \\
\hline LINTENS & 0.24 & 0.08 & 0.04 & 0.38 & Mineral oil refining & $\begin{array}{c}\text { Medical } \\
\text { equipment }\end{array}$ \\
\hline LABUND & 0.20 & 0.03 & 0.15 & 0.28 & Germany & Portugal \\
\hline SCALE & 184.4 & 196.2 & 36.0 & 1257.2 & Wooden containers & Iron and steel \\
\hline CENTRAL & 6198.4 & 2901.4 & 2293 & 10252 & Greece & $\begin{array}{c}\text { Belgium } \\
\text { INTERMIND }\end{array}$ \\
\hline INTERMCTR & 0.65 & 0.09 & 0.48 & 0.90 & Clay products & $\begin{array}{c}\text { Mineral oil } \\
\text { refining }\end{array}$ \\
\hline TEDUSE & 37.58 & 8.22 & 26.00 & 49.00 & Paper & $\begin{array}{c}\text { Railway rolling } \\
\text { stock }\end{array}$ \\
\hline
\end{tabular}

*For explanation of variables, see Section III. 2.

Table 2. Industrial Specialisation in the EU, 1989

\begin{tabular}{|l|l|r|r|r|r|r|r|r|r|r|r|}
\hline NACE & Description & GR & \multicolumn{1}{c|}{ P } & DK & B & \multicolumn{1}{c|}{ D } & E & F & I & UK & STD $^{1}$ \\
\hline $\mathbf{4 3 2 0}$ & Cotton & 1.85 & 2.34 & -1.36 & 0.32 & -0.32 & 0 & -0.09 & 0.3 & -0.41 & 1.14 \\
\hline $\mathbf{2 2 4 0}$ & $\begin{array}{l}\text { Non-ferrous } \\
\text { metals }\end{array}$ & 0.8 & -1.91 & -2.05 & 0.79 & 0.1 & -0.19 & -0.02 & 0 & 0.09 & 1.03 \\
\hline $\mathbf{4 1 5 0}$ & Fish, seafood & 0 & 0.8 & 1.5 & -1.14 & -1.05 & 0.44 & -1.1 & -1.44 & 0.2 & 1.03 \\
\hline $\mathbf{4 5 1 0}$ & Footwear & 0.25 & 1.33 & -1.3 & -1.73 & -1.06 & 0.33 & 0 & 0.8 & -0.13 & 1.01 \\
\hline $\mathbf{3 1 3 0}$ & $\begin{array}{l}\text { Second. transf. } \\
\text { of metals }\end{array}$ & -2.39 & n.a. & -0.03 & -0.28 & 0.03 & 0.73 & 0.86 & 0.22 & -0.44 & 1.01 \\
\hline $\mathbf{4 9 4 0}$ & $\begin{array}{l}\text { Toys, sports } \\
\text { goods }\end{array}$ & -0.18 & -1.87 & 1.29 & -1.52 & 0 & 0.12 & 0.64 & -0.32 & 0.31 & 0.99 \\
\hline $\mathbf{4 6 1 0}$ & Wood processing & 0.02 & 2.14 & -0.02 & -0.25 & -0.29 & 1.5 & 0.2 & -0.66 & n.a. & 0.97 \\
\hline $\mathbf{3 4 3 0}$ & $\begin{array}{l}\text { Industr. electr. } \\
\text { apparatus }\end{array}$ & -1.39 & -1.44 & n.a. & 0 & n.a. & 0.84 & -1.11 & 0.65 & 0.15 & 0.97 \\
\hline $\mathbf{3 6 2 0}$ & $\begin{array}{l}\text { Railway rolling } \\
\text { stock }\end{array}$ & 0.6 & n.a. & n.a. & 1.28 & -1.26 & 0.02 & -0.82 & -0.03 & n.a. & 0.92 \\
\hline $\mathbf{3 3 0 0}{ }^{2}$ & $\begin{array}{l}\text { Data processing } \\
\text { etc. }\end{array}$ & n.a. & n.a. & -0.68 & -1.79 & 0.07 & -1.74 & 0.27 & 0.29 & 0 & 0.92 \\
\hline $\mathbf{4 3 1 0}$ & Wool & 0 & 1.56 & -1.25 & 0.54 & -1.04 & -0.63 & -0.07 & 0.85 & 0.2 & 0.90 \\
\hline $\mathbf{3 5 0 0}$ & Motor vehicles & -2.1 & -0.93 & -1.52 & 0.14 & 0.4 & 0.03 & 0.28 & 0 & -0.16 & 0.88 \\
\hline
\end{tabular}

Notes: Specialisation index based on employment 
Table 2. Continued

\begin{tabular}{|c|c|c|c|c|c|c|c|c|c|c|c|}
\hline 3450 & $\begin{array}{l}\text { Radio, TV, sound } \\
\text { eqmt }\end{array}$ & -1.59 & 0.52 & n.a. & n.a. & -0.14 & -0.81 & 1.01 & 0.29 & 0 & 0.87 \\
\hline 3630 & $\begin{array}{l}\text { Cycles, } \\
\text { motorcycles }\end{array}$ & n.a. & 0.73 & 0.48 & n.a. & -0.87 & -0.17 & 0 & 0.76 & -1.56 & 0.8 \\
\hline 2450 & process. & 0.03 & 0.28 & 0 & -1.77 & -1.28 & 0.39 & -1.59 & -0.56 & 0.07 & 0.8 \\
\hline 2590 & $\begin{array}{l}\text { Misc. househ. } \\
\text { chemicals }\end{array}$ & 0.91 & -0.5 & -1.16 & n.a. & 1.32 & 0.11 & 0.85 & 0.2 & -0.13 & $\overline{0.8}$ \\
\hline 4380 & arpets etc. & 0.46 & 0.63 & 0 & 1.42 & -0.74 & -0.65 & -0.73 & -1.2 & 0.33 & 0.8 \\
\hline 4270 & $\begin{array}{l}\text { Brewing, malt- } \\
\text { ing }\end{array}$ & 0.22 & -0.26 & 1.11 & 0.59 & 0.07 & -0.07 & -1.16 & -1.35 & n.a. & 0.8 \\
\hline 4160 & Grain milling & 0.44 & 0.26 & 0.3 & -0.31 & -1.92 & 0.24 & -0.92 & -0.81 & n.a. & 0.8 \\
\hline 4140 & Fruit, vegeta & 1.95 & 0 & -0.2 & 0.48 & -0.82 & 0.82 & -0.2 & 0.02 & -0.49 & 0.82 \\
\hline 3640 & $\begin{array}{l}\text { Aerospace } \\
\text { (prod., repair) }\end{array}$ & 0.12 & n.a. & n.a. & n.a. & -0.52 & -1.39 & 0.62 & -0.13 & 0.88 & 0.8 \\
\hline $3440^{2}$ & $\begin{array}{l}\text { Telecom, } \\
\text { el.-medical etc. }\end{array}$ & .41 & a. & n.a. & 0.55 & 0.94 & -0.62 & 0 & -0.3 & 0.6 & $\overline{0.8}$ \\
\hline 4400 & Leather goods & 0 & 0.77 & -0.81 & -1.15 & -0.49 & 0.82 & 0.34 & 0.85 & -1.02 & 0.8 \\
\hline 3710 & $\begin{array}{l}\text { Precision } \\
\text { instruments }\end{array}$ & 0 & -0.31 & 0.39 & -0.05 & 1.57 & -0.11 & 0 & 0.85 & 1.94 & 0.8 \\
\hline 3280 & Misc. machinery & -0.67 & -1.36 & 1.28 & -0.01 & 0.64 & -0.59 & 0 & 0.26 & 0.63 & $\overline{0.8}$ \\
\hline 4290 & $\begin{array}{l}\text { Tobacco prod- } \\
\text { ucts }\end{array}$ & 1.7 & -0.59 & 0.14 & 0.33 & 0.88 & -0.16 & n.a. & 0.23 & 0.48 & .8 \\
\hline 4650 & $\begin{array}{l}\text { Misc. wood } \\
\text { products }\end{array}$ & .16 & n.a. & 0.8 & .06 & 0.71 & 1.23 & 66 & .06 & 0.09 & 0.7 \\
\hline 3610 & Shipbuilding & 0.88 & 0.42 & 0.82 & -0.94 & -1.17 & 0.19 & -0.98 & 0.36 & 0 & 0.7 \\
\hline 2230 & $\begin{array}{l}\text { Processing of } \\
\text { steel }\end{array}$ & -0.01 & -1.14 & -0.91 & 1.43 & 0.25 & -0.6 & 0.2 & 0 & 0.35 & 0.77 \\
\hline $\mathbf{3 7 2 0}^{2}$ & $\begin{array}{l}\text { Medical } \\
\text { equipment }\end{array}$ & n.a. & -1.15 & 0.66 & -1.08 & 0.68 & -1.06 & 0.16 & -0.06 & 0.05 & 0.7 \\
\hline 3240 & $\begin{array}{l}\text { Food/chemic. } \\
\text { machinery }\end{array}$ & n.a. & -1.46 & 0.74 & -0.41 & 0.73 & -0.52 & -0.05 & 0.57 & 0.04 & 0.7 \\
\hline 4640 & $\begin{array}{l}\text { Wooden } \\
\text { containers }\end{array}$ & 0.11 & -0.17 & -0.13 & -0.16 & -0.14 & 1.65 & 1.38 & 0.76 & n.a. & 0.7 \\
\hline 3250 & $\begin{array}{l}\text { Misc. heavy } \\
\text { plant }\end{array}$ & $\overline{1.94}$ & -0.5 & 0.73 & 0.08 & 0.29 & -0.36 & -0.16 & 0.13 & 0 & 0.7 \\
\hline 4110 & $\begin{array}{l}\text { Optical, } \\
\text { photographic eq. }\end{array}$ & 1.19 & 0.41 & 1.02 & 0 & -0.62 & 0.98 & -0.48 & -0.32 & -0.57 & 0.74 \\
\hline 2410 & Clay products & n.a. & 1.52 & -0.34 & -0.08 & -0.6 & 0.55 & -0.8 & 0.07 & 0.17 & 0.73 \\
\hline 3460 & $\begin{array}{l}\text { Domestic el. } \\
\text { appliances }\end{array}$ & 0.16 & -1 & n.a. & -1.75 & 0.02 & 0.06 & -0.02 & 0.39 & -0.12 & 0.72 \\
\hline 4120 & Slaughtering etc. & -0.19 & -0.28 & 1.75 & 0 & -0.49 & 0.74 & 0.78 & -0.07 & 0.62 & 0.71 \\
\hline 4630 & $\begin{array}{l}\text { Carpentry, } \\
\text { joinery }\end{array}$ & -1.03 & 0.78 & 1.14 & -0.15 & -0.12 & 1.03 & 0 & -0.38 & 0.04 & 0.71 \\
\hline
\end{tabular}


Table 2. Continued

\begin{tabular}{|c|c|c|c|c|c|c|c|c|c|c|c|}
\hline 3270 & $\begin{array}{l}\text { Specialised } \\
\text { machinery }\end{array}$ & n.a. & n.a. & 0 & -0.79 & 1.09 & -0.38 & -0.75 & 0.58 & 0.3 & 0.70 \\
\hline 2420 & $\begin{array}{l}\text { Cement, lime, } \\
\text { plaster }\end{array}$ & 1.51 & 0.09 & n.a. & -0.1 & -0.53 & 0.31 & -0.15 & 0.25 & -0.84 & 0.70 \\
\hline 4360 & Knitting & 1.17 & 1.2 & -0.18 & -0.58 & -0.81 & -0.14 & 0 & 0.35 & 0.02 & 0.69 \\
\hline 4190 & $\begin{array}{l}\text { Bread, flour } \\
\text { products }\end{array}$ & -0.17 & 1 & -0.28 & 0.17 & 0 & 1.33 & -0.35 & -0.64 & 0.9 & 0.69 \\
\hline $3420^{2}$ & $\begin{array}{l}\text { Electr. } \\
\text { machinery/plant }\end{array}$ & -0.48 & -0.53 & n.a. & -0.38 & 1.22 & n.a. & 0.78 & 0 & 0.36 & 0.68 \\
\hline 3260 & $\begin{array}{l}\text { Transmission } \\
\text { equipment }\end{array}$ & n.a. & n.a. & -1.04 & -0.13 & 0.77 & -0.92 & 0 & 0.42 & 0.17 & 0.67 \\
\hline 4210 & Cocoa, sweets & 0.48 & -0.6 & 0.89 & 0.43 & -0.19 & 0 & -0.02 & -1.26 & 0.25 & 0.64 \\
\hline 3210 & $\begin{array}{l}\text { Agricultural } \\
\text { machinery }\end{array}$ & -0.81 & -0.47 & 1.17 & 0.3 & 0 & -0.04 & 0.04 & 0.66 & -0.52 & 0.62 \\
\hline 3230 & $\begin{array}{l}\text { Textile } \\
\text { machinery }\end{array}$ & n.a. & 0.01 & -0.42 & 0.7 & 0.86 & -0.01 & -0.63 & 0.67 & -0.64 & 0.61 \\
\hline 3220 & Machine tools & n.a. & -0.94 & -0.29 & 0.04 & 0.93 & -0.05 & -0.4 & 0.77 & 0.16 & 0.61 \\
\hline 2210 & Iron, steel & -0.31 & -0.73 & -0.91 & 0.96 & 0.14 & 0.2 & -0.16 & 0.35 & n.a. & 0.60 \\
\hline 1400 & $\begin{array}{l}\text { Mineral oil } \\
\text { refining }\end{array}$ & 1.61 & 0 & -0.32 & -0.18 & 0 & 0.06 & 0.69 & 0.58 & -0.05 & 0.60 \\
\hline 4370 & Textile finishing & 0.82 & n.a. & -0.85 & 0.28 & -0.46 & 0.18 & -0.23 & 0.82 & -0.28 & 0.60 \\
\hline 2560 & $\begin{array}{l}\text { Misc. indust. } \\
\text { chemicals }\end{array}$ & -0.59 & 0.17 & -1.14 & 0.63 & n.a. & 0.14 & 0.38 & -0.53 & -0.16 & 0.58 \\
\hline $4530^{2}$ & $\begin{array}{l}\text { Clothing, } \\
\text { accessories }\end{array}$ & 0.92 & 0.75 & -0.76 & -0.15 & -0.74 & 0.07 & -0.25 & 0.25 & 0 & 0.58 \\
\hline 4390 & Misc. textiles & 1.33 & 0.98 & -0.29 & 0 & -0.21 & 0.15 & 0.3 & -0.03 & -0.3 & 0.58 \\
\hline 4230 & $\begin{array}{l}\text { Misc. food } \\
\text { products }\end{array}$ & 0.87 & -0.72 & 0.65 & -0.13 & 0 & 0.37 & -0.39 & -0.42 & 0.58 & 0.55 \\
\hline 2510 & $\begin{array}{l}\text { Basic industr. } \\
\text { chemicals }\end{array}$ & 0 & -0.91 & -0.56 & 0.6 & 0.69 & -0.59 & -0.01 & 0.21 & 0.21 & 0.55 \\
\hline 3140 & $\begin{array}{l}\text { Structural metal } \\
\text { prods }\end{array}$ & -0.88 & n.a. & 0.44 & 0.38 & -0.31 & 0.52 & -0.7 & 0.23 & -0.34 & 0.55 \\
\hline 2480 & Ceramic goods & 0 & 0.67 & -0.11 & -1.1 & -0.41 & 0.31 & -0.5 & 0.41 & 0.02 & 0.54 \\
\hline 3120 & $\begin{array}{l}\text { Forging, } \\
\text { pressing etc. }\end{array}$ & n.a. & n.a. & n.a. & -1.13 & -0.12 & 0.01 & 0.42 & 0.02 & -0.01 & 0.52 \\
\hline 2550 & $\begin{array}{l}\text { Paint, varnish, } \\
\text { ink }\end{array}$ & -0.28 & 0 & 0.45 & 1.22 & 0.76 & -0.06 & -0.08 & -0.27 & 0.01 & 0.51 \\
\hline 3110 & Foundries & -1.4 & 0.21 & -0.27 & -0.57 & 0.07 & 0 & 0.01 & 0.08 & -0.04 & 0.50 \\
\hline 4280 & Soft drinks & 0.99 & 0.37 & n.a. & -0.02 & -0.36 & 0.73 & -0.14 & -0.32 & 0.02 & 0.49 \\
\hline $\mathbf{3 1 5 0}^{2}$ & $\begin{array}{l}\text { Boilers, } \\
\text { reservoirs, tanks }\end{array}$ & -0.66 & -0.02 & 0.33 & 0.12 & 0.25 & -0.19 & 1.05 & -0.34 & 0 & 0.48 \\
\hline 4550 & $\begin{array}{l}\text { Household } \\
\text { textiles }\end{array}$ & -0.59 & n.a. & 0.37 & 0 & -0.89 & 0.13 & n.a. & -0.55 & 0.19 & 0.48 \\
\hline 4130 & Dairy products & 0.48 & 0.34 & 0.75 & 0 & -0.85 & -0.1 & 0.37 & -0.06 & -0.2 & 0.47 \\
\hline
\end{tabular}


Table 2. Continued

\begin{tabular}{|c|c|c|c|c|c|c|c|c|c|c|c|}
\hline 4220 & Animal feed & -0.69 & 0.36 & 0.01 & 0.02 & -1.09 & 0.17 & 0 & -0.53 & -0.13 & 0.46 \\
\hline 2470 & Glass, glassware & -0.58 & 0.16 & -0.95 & 0.62 & -0.12 & 0 & 0.26 & 0.02 & -0.1 & 0.46 \\
\hline 4810 & Rubber products & n.a. & -0.58 & -0.76 & -0.71 & 0.01 & 0.1 & 0.43 & 0.1 & -0.01 & 0.44 \\
\hline 4730 & Printing etc. & -0.18 & -0.02 & 0.74 & 0.08 & -0.39 & 0 & 0.15 & -0.61 & 0.57 & 0.43 \\
\hline 3470 & $\begin{array}{l}\text { Electric lamps, } \\
\text { lighting }\end{array}$ & n.a. & 0.13 & n.a. & 0.63 & 0 & -0.45 & -0.33 & -0.58 & 0.12 & 0.42 \\
\hline 4620 & $\begin{array}{l}\text { Semi-finished } \\
\text { wood pr. }\end{array}$ & 0.93 & 0.05 & -0.06 & 0.23 & -0.41 & 0.27 & -0.2 & -0.15 & n.a. & 04 \\
\hline $4710^{2}$ & $\begin{array}{l}\text { Pulp, paper, } \\
\text { board }\end{array}$ & 0.7 & 0.76 & -0.2 & 0.11 & -0.13 & 0.04 & -0.01 & 0 & -0.17 & $\overline{02}$ \\
\hline 4670 & $\begin{array}{l}\text { Wooden } \\
\text { furniture }\end{array}$ & -0.61 & -0.14 & 0.54 & 0.02 & -0.16 & 0.47 & -0.31 & 0.08 & 0 & 0.36 \\
\hline 2580 & $\begin{array}{l}\text { Soap, cosmetics, } \\
\text { etc. }\end{array}$ & 0.8 & -0.05 & -0.4 & -0.06 & 0.05 & 0.16 & 0.46 & -0.12 & 0 & 0.35 \\
\hline 2430 & Concrete etc. & 0 & -0.02 & 0.8 & 0.32 & -0.25 & 0.33 & -0.07 & 0.08 & -0.2 & 0.33 \\
\hline $4720^{2}$ & $\begin{array}{l}\text { Paper/board } \\
\text { processing }\end{array}$ & -0.14 & -0.4 & 0.47 & 0.16 & 0 & -0.14 & 0.32 & -0.13 & 0.59 & 0.33 \\
\hline 2220 & Steel tubes & 0.17 & n.a. & 0.15 & -0.12 & 0.11 & -0.6 & -0.21 & 0.28 & -0.5 & 0.33 \\
\hline 2570 & Pharmaceuticals & 0.12 & -0.36 & 0.59 & -0.07 & -0.32 & -0.03 & 0.11 & 0.25 & 0 & 0.29 \\
\hline $3160^{2}$ & $\begin{array}{l}\text { Metal goods, } \\
\text { tools }\end{array}$ & $\overline{0}$ & 0.18 & 0.14 & -0.51 & 0.19 & 0.09 & -0.38 & -0.42 & -0.1 & 0.28 \\
\hline $3410^{2}$ & $\begin{array}{l}\text { Insulated wires, } \\
\text { cables }\end{array}$ & 0.04 & 0.23 & n.a. & -0.38 & n.a. & -0.43 & 0 & -0.14 & 0.21 & 0.26 \\
\hline 4830 & Plastics & -0.23 & -0.33 & 0.34 & -0.06 & 0.15 & 0 & 0 & 0.03 & 0.08 & 0.20 \\
\hline 2601 & $\begin{array}{l}\text { Man-made } \\
\text { fibres }\end{array}$ & 0 & -0.35 & -0.14 & 0.34 & 0.13 & -0.15 & 0.11 & 0.03 & -0.03 & 0.20 \\
\hline$S T D^{1}$ & 0.92 & 0.85 & 0.80 & 0.70 & 0.66 & 0.58 & 0.54 & 0.51 & 0.45 & & \\
\hline
\end{tabular}

Source: Eurostat (Series: "Structure and Activity of Industry")

${ }^{1}$ standard deviations

2“procurement sensitive” sectors, according to CEC (1997) 